\title{
Obstacles and implementation of accounting software system in Small Medium Enterprises (SMEs): Case of South Asian perspective
}

Mohammad Mazibar Rahman ${ }^{1}$, Md. Main Uddin Ahammed ${ }^{2}$, Md. Abdur Rouf ${ }^{3}$ and Mohammad Main Uddin ${ }^{1}$

\begin{abstract}
:
Small and medium enterprises (SMEs) have long been considered as the principle driving force of Bangladesh's economy. Along with stimulating private ownership and entrepreneurial skills, SMEs are flexible and can adapt quickly to changing market demand and supply. The aim of this study was to show that how the factors of barrier affected practicing of accounting software system in SMEs of Bangladesh. However, to get an exclusive finding, total 300 firms were randomly selected as a respondent and surveyed to get the specific answers of the specific questionnaire. Finally, the result of this study suggested the proper application and use of accounting software system ensured strong responsibility and accountability of the business enterprise and it also assisted the owner and policy makers of the firm's to better understanding about their performance and improvement. With employing accounting software technology, small and medium business enterprises can reduce its operating cost and increase its profitability and competitive advantages.
\end{abstract}

Keywords: Accounting Software (AC), Small Medium enterprises (SMEs), Barrier and Implementation

\section{Introduction}

In today's IT centric world, organization clearly can neither operate nor survivemuch less thrive- without information system that allow the organization to move forward in a controlled, yet competitive, manner (U.Gelinas, R. et al, 2011). Several authors have pointed out that the relationship between information technology (IT) and firm performance appears to be the most complex, penetrating and unpredictable in the field of accounting information systems (AIS) (Pedro Ruivo et al, 2014). Generally, firms adopt IT to improve their competiveness and business performance. The study of accounting with the recognition of information system is a business resource such as- raw materials, capital, labor and information stated vital to the survival of contemporary of business organization (James A. Hall, 2010).

\footnotetext{
${ }^{1}$ Lecturer, Department of Accounting, Hajee Mohammad Danesh Science and Technology University, Bangladesh.

${ }^{2}$ Lecturer, Department of Finance \& Banking, Hajee Mohammad Danesh Science and Technology University, Bangladesh.

${ }^{3}$ Lecturer, Department of Marketing, Hajee Mohammad Danesh Science and Technology University, Bangladesh.
} 
Early contributions in the AIS literature frequently took the form of introductions to the "new" technology coupled with speculations on its implication for management accounting, accountants and control. Perhaps the major problem with these works is their overly simplified assumption that the design and implementation of a management accounting system is about choosing certain solutions, thereby ignoring the post-implementation impact on firms' strategy and organization (Nicolaou, 2004; Granlund, 2011). Accounting software system is a tool which, when incorporated into the field of Information and Technology systems (IT), were designed to help in the management and control of topics related to firms' economic-financial area. But the stunning advance in technology has opened up the possibility of generating and using accounting information from a strategic viewpoint. Since this is important for all firms, it is more important even for medium-sized and small ones which need this information to deal with a higher degree of uncertainty in the competitive market (El Louadi , 1998).

Stefanou (2006) observed that although information system does not require a computer to function, the computerization of the accounting function, the term AIS is used primarily to denote the computer-based information system. Although in comparative organizational cultures among countries Bangladesh appear as a country with high resistance to changes that delivers uncertainty of companies' investments of IT (Hofstede, 2001). Because of its important role in economics growth, small and medium business enterprises has to increase its capability and practice of accounting software in order to win the global competition with foreign economics institution. The paper was organized into five sections. In section 2 we describe the methodology used in this particular sample. The following section reports the finding and discussion. The paper is concluded in section 5.

\section{Literature review:}

Along with the improvements in the technology, information systems have been computerized which have replaced manual accounting systems with computerized ones (Fowzia \& Nasrin, 2011). In the modern day economy, managerial skills for undertaking planning, marketing, and cash-flow management are vital for survival of a small and medium enterprise (Zaman \& Islam, 2011). SMEs all over the world have been playing a crucial role in promoting economic development as well as industrial production (S. M. Akterujjaman, 2010). Of the total industrial units about $90 \%$ are the SMEs. Recent estimate has revealed that there are 0.6 million SMEs in Bangladesh which are gradually occupying a remarkable position in the competitive market structure. These SMEs are the breeding ground of the large enterprises through a process of natural selection. The highly successful and innovative SMEs of today grow into the large firms and multinationals of tomorrow (MS Reza, 2012). Information, be it financial or nonfinancial, is one of the key factors for success in this global-economy era (Brecht \& Martin, 1996). Further, the SMEs have seen high failure rate (Ballantine et al., 1998) due to their inability to influence market price by altering the output levels (Storey \& Cressy, 1995). They also have small market shares, are unable to mount barriers to entry to their industry and are heavily dependent on a small number of customers (Storey \& Cressy, 1995).

In computerized system, computers are used in processing data and in disseminating accounting information to interested users. Now-a-days most of the small business organizations eventually replace their manual accounting system

8 International Journal of Science and Business | www.ijsab.com 
with computerized accounting system. Accounting software programs that gather the various accounting information related to sales, purchases, receivables, payables, cash receipts, cash disbursements, and payroll. And in this procedure the financial statement is generated (Islam, 2010). In other words, there are improvements in administrative management regarding accountancy and finance. By using Accounting Software, it is possible to gauge the risk of some operations or predict future earnings with sophisticated software applications. Despite of some authors who postulate that the direction of the cause effect relationship is only that companies achieve a high performance when they can afford the implementation of certain technological developments (Damanpour and Gopalakrishnan, 2001). Others indicate that firm performance drops just after the implementation, taking several years to realize the benefits from accounting software adoptions (Wah, 2000). Effectiveness of accounting information system also depends on the perception of decision-makers on the usefulness of information generated by the system to satisfy informational needs for operation processes, managerial reports, budgeting and control within organization (Sajady et al, 2008).

The globalization and current state of the economy are forcing many enterprises to change in order to survive. To compete in global markets many SMEs need to develop new business strategies and employ technologies. A better understanding of the ways in which SMEs use and extract value from technologies, like information technology, is necessary because earlier research in the area is limited and mostly out-of-date due to the rapidly changing costs of using IT, and the resulting increased adoption by SMEs (Chuang et al., 2009). Nicolaou and Bhattacharya (2006) state that any organizational benefits that accrue to the adopting firms come as a result of the baseline ERP adoption event, based on the nature, enhancements and timing (early and late) of such post-implementation changes.

The characteristics of the accounting information system, to which the environmental, organizational and decision making variables will be related are: information load, centralization of reporting, cost allocation methods (with reference to both amount and timing), frequency of reporting, method of reporting (e.g. Statements, raw data, charts, pictures), time element of information (e.g. ex ante vs ex post data), performance evaluation, measurement of events (e.g. financial vs nonfinancial data and external vs internal data), and valuation methods (e.g. historical cost vs market value vs price level adjusted information) (Lawrence A. Gordon and Danny Miller, 1976). This study shows the practice of accounting software and find out major constraint that influence on SMEs accounting system. Then the study has mentioned some recommendation in development of accounting software practice in SMEs sector of Bangladesh.

\subsection{Overview of SMEs in Bangladesh:}

SMEs are recognized as engine of economic growth and employment generation for sustainable industrialization in both developed and developing countries of the world. In context of Bangladesh, there is no alternative of small and medium enterprises for rapid industrialization and national economic growth through lower capital investment and employment generation (Retrieved 2014, http://www.smef.org.bd/). In Bangladesh, SMEs including micro enterprises comprise over 99 per cent of all industrial units, contributing over 85 per cent of industrial employment. Focusing on the 10+ units, small units constitute 87.4 per 
cent, followed by medium and large units comprising 5.7 and 6.9 per cent respectively. In other words, 81 thousand SMEs all together constitute more than 93 per cent of the total $10+$ units. Again, focusing on the $10+$ units, small units contribute to 35 per cent of the employment, followed by medium and large units comprising 8.8 and 56.0 per cent respectively. In other words, SMEs employ 1.3 million people, constituting 44 percent of employment generated by $10+$ units (A.K.M. Helal uz Zaman and Md. Jahirul Islam, 2011).

For the purpose of this study, a business enterprise is considered small or micro if it satisfies any one of the following conditions: As per industrial policy 2005 of Bangladesh, larger industry is defined to include all industrial enterprise having more than 100 workers and /or having a fixed capital of over Tk.100 million. Medium industries covers enterprises employing between Tk.15 million and Tk.100 millions. Small industry means enterprises having fewer than 25 workers and/or with a fixed capital investment of less than Tk.15 millions.

As per Bangladesh Bank Definitions: Small enterprise means an entity, ideally not a public limited company that does not employ more than 60 people if it is a manufacturing concern and 20 persons if it is trading concern and 30 people if it is a service concern and also fulfills the following criteria: (1) A service concern with total assets at cost excluding land and building for To 50,000 to 30 lac. (2) A trading concern with total assets at cost excluding land and building from To 50,000 to 50 lac. (3) A manufacturing concern with total assets at cost excluding land and building form Tk.50, 000 to Tk.1 crores.

\subsection{Objectives of the Study:}

The main objectives of this study are as follows: $\square$ To show the practice of accounting software system in SMEs of Bangladesh. $\square$ To find out the major barriers in implementing accounting software system for the SMEs. $\square$ To recommend for overcoming the barriers related to Accounting Software System.

\section{Research method and measure:}

The study was mainly based on empirical analysis of both primary and secondary data. A structured survey questionnaire has been used for primary data collection. We sampled 300 SMEs from the SME Foundation Database of Bangladesh based on employee size (www.smef.org.bd). Out of the 300 questionnaire, 220 responses were received. In order to ascertain the barrier of accounting software practicing, we focused on SMEs that adopt accounting software system in their business. Review Scholar articles and findings were presented by the use of descriptive statistics. Secondary sources were from different local and international published articles, books, websites, and seminar papers etc.

The study showed background and training of the Managing Directors (MD) of respondent firms. For this purpose, 13\% of the MDs have Masters Degree and 48\% have a Bachelor. MDs of the respondent firms also have professional training in diverse disciplines: Accounting and Finance (36\%), Economics (5\%), Marketing (23\%), Engineering (17\%), Computer Science (15\%) and Human resource (4\%). In this study, the features of the firms represented based on, size and ownership. On the size, the firms were categorized as: micro representing 24 firms (11\%) of valid respondents, small total 112 which indicates $(51 \%)$ and medium representing 84 firms (38\%). In terms of ownership, majority $82 \%$ of the firms were Bangladeshi owned. Foreign firms were made up of $16 \%$ of respondents and $2 \%$ of total valid 
respondent firms were owned by both Bangladeshi and foreigners. The form of business organization was also identified as sole proprietorships made up of $42 \%$ of the total respondent firms, $4 \%$ of the valid respondent firms organized as partnership and the remaining 54\% were organized as limited liability companies. The study also illustrated total thirteen industries identified as Manufacturing (13\%), Printing \& Publication (6\%), Advertising Agency (5\%), Courier Service (8\%), Fuel \& CNG (3\%), Electrical \& Electronics (21\%), Motor Workshop (7\%), Construction \& Mining (2\%), Hotel \& Hospitality (9\%), IT Service (4\%), Medical Services (4\%), Wholesale \& Retail Stationery (15\%) and Catering Services (3\%).

\section{Result and Discussion:}

The results as indicated in Table 1 depicted that almost maximum of the respondents use computer system and accounting software in their operations. $73 \%$ respondents use computer systems and 53\% practiced accounting software as part of their daily accounting record.

Table 1: Status of Computer and Accounting Software Usage

\begin{tabular}{|l|l|l|l|}
\hline Pattern & Yes & No & Total \\
\hline $\begin{array}{l}\text { Use of computer } \\
\text { system in } \\
\text { operations }\end{array}$ & $73 \%$ & 60 & 220 \\
Percentage (\%) & $73 \%$ & 100 \\
\hline $\begin{array}{l}\text { Use of accounting } \\
\text { software in } \\
\text { operation } \\
\text { Percentage (\%) }\end{array}$ & 116 & 104 & 220 \\
\hline
\end{tabular}

The result of this study in table 2 showed that, Tally, Troyee, QuickBooks, Sage, and Excel were

widely using accounting software that SMEs adopted. The majority of the SMEs $(65 \%)$ were

interested in excel based accounting system while $16 \%$ preferred the use of Tally software, $10 \%$

used Troyee and 6\% respondent used Quick Books.

Table 2: Practicing of Accounting Software in SMEs of Bangladesh

\begin{tabular}{|l|c|c|}
\hline $\begin{array}{l}\text { Kinds of accounting } \\
\text { software use in SME: }\end{array}$ & Amount & Percentage \\
\hline Tally & 26 & $16 \%$ \\
\hline Troyee & 16 & $10 \%$ \\
\hline QuickBooks & 9 & $6 \%$ \\
\hline Sage & 5 & $3 \%$ \\
\hline Excel database & 96 & $60 \%$ \\
\hline Others & 8 & $5 \%$ \\
\hline Total & 160 & $100 \%$ \\
\hline
\end{tabular}




\subsection{Barriers in adoption of accounting software in SMEs:}

In this study, Table 4 shows that $79 \%$ of the firms feel that a lack of infrastructure and environment has a major barrier, $15 \%$ became undecided and $6 \%$ firms detract with this factor. Almost $34 \%$ of the decision-makers within the surveyed firms feel that there is not enough resource available at their disposal about relevant and effective technologies and 39\% were undecided and 27\% disagreed. Of the respondents, $49 \%$ feel that the system is awkward and critical. About $91 \%$ of the firms feel there is not enough training and support from the top management in the firms. Other barriers identified include: government regulations and requirements and bad experiences in the past.

Table 3: Factors of barrier in implementing Accounting Software in SMEs.

\begin{tabular}{|l|l|l|l|l|l|l|}
\hline Factors of barrier & $\begin{array}{l}\text { Strong } \\
\text { view }\end{array}$ & Percentage & No Effect & Percentage & Detract & Percentage \\
\hline $\begin{array}{l}\text { Infrastructure and } \\
\text { environment. }\end{array}$ & 127 & $79 \%$ & 24 & $15 \%$ & 9 & $6 \%$ \\
\hline Constrained resources & 55 & $34 \%$ & 62 & $39 \%$ & 43 & $27 \%$ \\
\hline $\begin{array}{l}\text { Awkward of the } \\
\text { system }\end{array}$ & 79 & $49 \%$ & 25 & $16 \%$ & 56 & $35 \%$ \\
\hline $\begin{array}{l}\text { Training \& } \\
\text { Manpower }\end{array}$ & 145 & $91 \%$ & 2 & $1 \%$ & 13 & $8 \%$ \\
\hline $\begin{array}{l}\text { Frequent breakdown } \\
\text { error }\end{array}$ & 38 & $24 \%$ & 92 & $59 \%$ & 28 & $17 \%$ \\
\hline
\end{tabular}

\subsection{Hypothesis and Analysis:}

To measure whether five major factors are same or not for implementing accounting software in SMEs, the authors have applied Mean value and ANOVA analysis technique. The result evaluates using null and alternative hypotheses.

H1: The five factors have equal impact of implementing Accounting Software in SMEs of Bangladesh.

Table 4: Mean value

\begin{tabular}{|l|l|l|l|l|}
\hline $\begin{array}{l}\text { Infrastructure and } \\
\text { environment }\end{array}$ & $\begin{array}{l}\text { Constrained } \\
\text { resources }\end{array}$ & $\begin{array}{l}\text { Awkward of the } \\
\text { system }\end{array}$ & $\begin{array}{l}\text { Training } \\
\text { Manpower }\end{array}$ & $\begin{array}{l}\text { Frequent } \\
\text { breakdown }\end{array}$ \\
\hline 381 & 165 & 237 & 435 & 114 \\
\hline 48 & 124 & 50 & 4 & 188 \\
\hline 9 & 43 & 56 & 13 & 28 \\
\hline$\Sigma 146$ & $\Sigma 332$ & $\Sigma 343$ & $\Sigma 452$ & $\Sigma 330$ \\
\hline
\end{tabular}

The table 5 shows the ANOVA analysis of the factors affecting implementation of Accounting Software in SMEs of Bangladesh. These five factors do not vary and state the equal impact due to the calculated value 0.00293 and the table value for $\mathrm{F}(4,10)$ at the $5 \%$ level of significance is 3.478 . Thus, we reject the alternative hypothesis and accept the null hypothesis. 
Table 5: ANOVA Analysis

\begin{tabular}{|c|c|c|c|c|}
\hline $\begin{array}{l}\text { Source of } \\
\text { Variation }\end{array}$ & $\begin{array}{l}\text { Sum of } \\
\text { Squares (SS) }\end{array}$ & $\begin{array}{l}\text { Degree of } \\
\text { Freedom (df) }\end{array}$ & Mean Square (MS) & $\begin{array}{l}\text { Variance } \\
\text { Ratio F } \\
\end{array}$ \\
\hline $\begin{array}{l}\text { Between } \\
\text { Samples }\end{array}$ & $\begin{array}{l}=27145.55- \\
26600.08 \\
=545.08\end{array}$ & $5-1=4$ & $\begin{array}{l}\mathrm{MSB}=545.08 / 4 \\
=136.27\end{array}$ & \multirow{3}{*}{$\begin{array}{l}F=136.27 / 465234.45 \\
=0.00293\end{array}$} \\
\hline $\begin{array}{l}\text { Within } \\
\text { Samples }\end{array}$ & $\begin{array}{l}=492380- \\
27145.55 \\
=465234.45\end{array}$ & $15-5=10$ & $\begin{array}{l}\text { MSW=465234.45/10 } \\
=46523.45\end{array}$ & \\
\hline Total & $\begin{array}{l}=492380- \\
26600.47 \\
=465734.53\end{array}$ & $15-1=14$ & & \\
\hline
\end{tabular}

\section{Conclusion and recommendation:}

Any business that is on the up needs timely information about its financial performance such as yearly, quarterly, or sometimes even monthly so on. Shareholders are not involved in the day-to-day running of the business who will also want information about business performance. Computer base accounting system makes the business organization more dynamic and competitive in their sector. This study examines major factors of barrier and the result shows that these factors have same level of impact for implementing accounting software in SMEs sector. The result of the study showed that in Bangladesh practicing of accounting software should not reach very much familiar stage due these major factors of barrier. Bangladesh categorized as low income country having some severe problems like employment, energy crisis, low per capita income, poverty, security dearth and dependency on imported goods. SMEs can play a vital role for the development of economy of Bangladesh as well as create employment opportunities in the country. Though the factors are critical, firstly, proper allocation of resources and infrastructure development help the business owner to put an extra emphasize on accounting software practicing in their business. Different professional training institute need to establish for skill manpower development which assists them to understand the awkward system of computer based accounting system. Furthermore, Government and other regulatory authority should take necessary steps to grow and practice of accounting software. Consequently, this study try to capture a snapshoot for practicing and implementing of accounting software in SME sector of Bangladesh and a welldefined strategy in favor of investing in accounting software and favoring their use needs an organizational culture to accompany it, even if in the short term allocating resources to accounting software increase performance, productivity as well as responsibility of the business organization.

\section{Reference:}

A.K.M. Helal uz Zaman \& Md. Jahirul Islam (2011) "Small and Medium Enterprises Development in Bangladesh: Problems and Prospects", ASA University Review, vol. 5, no.1: 145-160

Ballantine, J., M. Levy \& P. Powell (1998) "Evaluating information systems in small and medium-sized enterprises: issues and evidence" European Journal of Information Systems, vol. 7:241-251 
Brecht, H. D. \& M. P. Martin (1996): "Accounting information systems: The challenge of extending their scope to business and information strategy", Accounting Horizons, vol. 10, no. 4:16-22

Chuang T, Nakatani K, \& Zhou D. (2009) "An exploratory study of the extent of information technology adoption in SMEs: an application of Upper Echelon Theory", Journal of Enterprize Information Management, vol. 22:183-96

Damanpour, F. \& Gopalakrishnan, S. (2001): "The dynamics of the adoption of product and processinnovations in organizations", Journal of Management Studies, vol. 38, no.1: 45-65 Ellouadi, M. (1998): "The relationship among organization structure, information technology and information processing in small Canadian firms", Canadian Journal of Administrative Science, vol. 15, no. 2: 99-180

Fowzia \& Nasrin (2011) "Appreciation of Computerized Accounting System in Financial Institutions in Bangladesh", World Review of Business Research, vol. 1, no. 2:1-9

Granlund M. (2011) "Extending AIS research to management accounting and control issues: a research note", International Journal of Accounting Information System, vol. 12: 3-19

HOFSTEDE, G. (2001) Culture's Consequences: Comparing Values, Behaviors, Institutions, and Organizations across Nations, 2nd Edition, Sage Publications, USA

Islam, Md Robiul (2010) Basic Accounting, 1st Edition, Hazi Book Deport Publications, Bangladesh

James A. Hall (2010) Accounting information systems, 7th Edition, Cengage Learning, USA

Lawrence A. Gordon \& Danny Miller, (1976) "A contingency framework for the design of accounting information systems", Accounting, Organizations and Society, vol.1, no.1: 59-69

MS Reza (2012) "Contribution of Equity Entrepreneurship Fund towards Development of S.M.E Sector in Bangladesh", Asian Institute of Technology, School of Management, Project Paper, Thailand

Nicolaou AI (2004); "Firm performance effects in relation to the implementation and use of enterprise resource planning systems", Journal of Information System, vol.18:79-105

Nicolaou AI \& Bhattacharya S.(2006) "Organizational performance effects of ERP systems usage: the impact of post-implementation changes", International Journal of Accounting Information Systems, vol.7:18-35.

Pedro Ruivo, Tiago Oliveira \& Miguel Neto (2014) "Examine ERP postimplementation stages of use and value: Empirical evidence from Portuguese SMEs”, International Journal of Accounting Information Systems, vol.15:166-184 
Sajady, H, Dastgir, M \& Hashem, H (2008) "Evaluation of the effectiveness of Accounting Information Systems", International Journal of Information Science and Technology, vol. 6, no. 2: 785-793

S. M. Akterujjaman (2010) "Problems and Prospects of SMEs Loan Management: A Study on Mercantile Bank Limited, Khulna Branch", Journal of Business and Technology (Dhaka), vol. 5, no. 2: 38-52

Stefanou, C. (2006)" The Complexity and the Research Area of AIS", Journal of Enterprise Information Management, vol. 19, no. 1: 9-12

Storey, D. J., and R. Cressy (1996) "Small business risk: A firm and bank perspective", Working Paper, SME Centre, Warwick Business School, UK

Ulric G., Richard D., \& Patrick W. (2011) Accounting Information Systems, 9th Edition, Cengage Learning, USA

WAH, L. (2000) "Give ERP a chance”, Management Review, vol. 89, no. 3: 20-24. Zaman, AKM Helaluz \& Islam, Md Jahirul (2011): "Small and Medium Enterprises Development in Bangladesh: Problems and Prospects", ASA University Review; vol. 5, no. 1: 25- 42.

\section{Online Reference:}

1. SME Foundation; www.smef.org.bd (Accessed on 15 August, 2014).

2. Bangladesh Bank; www.bangladesh-bank.org (Accessed on 30 December, 2014)

\section{Citation:}

Rahman, M. M., Ahammed, M. M. U., Rouf, M. A., \& Uddin, M. M. (2017). Obstacles and implementation of accounting software system in Small Medium Enterprises (SMEs): Case of South Asian perspective. International Journal of Science and Business, 1(1), 7-15.

Retrieve form http://ijsab.com/wp-content/uploads/2.pdf

$<$ meta name="citation_title" content=" Obstacles and implementation of accounting software system in Small Medium Enterprises (SMEs): Case of South Asian perspective."> $<$ meta name="citation_author" content=" Rahman, M. M."> $<$ meta name="citation_author" content=" Ahammed, M. M. U."> $<$ meta name="citation_author" content=" Rouf, M. A." > $<$ meta name="citation_author" content=" Uddin, M. M."> <meta name="citation_publication_date" content="2017/02/04"> $<$ meta name="citation_journal_title" content=" International Journal of Science and Business "> $<$ meta name="citation_volume" content $=" 1 ">$ $<$ meta name="citation_issue" content="1"> $<$ meta name="citation_firstpage" content="7"> $<$ meta name="citation_lastpage" content $=" 15 ">$ $<$ meta name="citation_pdf_url" content="http://ijsab.com/wp-content/uploads/2.pdf"> 